\title{
Impact of early castration and health status on the performance of Holstein-Friesian and beef crossbred calves
}

\author{
Zofia Wielgosz-Groth ${ }^{1}$, Monika Sobczuk-Szul ${ }^{1}$, Zenon Nogalski ${ }^{1}$, \\ Cezary Purwin ${ }^{2}$, Paulina Pogorzelska-Przybyłek ${ }^{1}$, Rafał Winarski ${ }^{3}$ \\ ${ }^{1}$ Department of Cattle Breeding and Milk Evaluation, \\ ${ }^{2}$ Department of Animal Nutrition and Feed Sciences, \\ ${ }^{3}$ Department of Commodity Science and Animal Raw Material Processing, \\ University of Warmia and Mazury in Olsztyn, 10-958 Olsztyn-Kortowo, Poland \\ monika.sobczuk@uwm.edu.pl
}

Received: August 5, $2015 \quad$ Accepted: May 10, 2016

\begin{abstract}
Introduction: This article presents the analysis of the correlation between the category and health status of calves and the results of their rearing and levels of selected blood parameters. Material and Methods: The study included 105 Polish HolsteinFriesian and beef (Limousine, Charolaise and Hereford) crossbred calves. Young bulls were purchased at the age of two to four weeks. The animals underwent quarantine, were dehorned, and 46 young bulls were castrated. The germ horns were removed by burning out. Castration was carried out with a bloodless method using a rubber band. The calves were kept in groups and fed a milk replacer administered via teats from automated milk-feeding stations. After the period of milk feeding, the calves were fed grass silage ad libitum and a concentrate at $2.5 \mathrm{~kg} /$ animal/day. The calves were weighed every two weeks. Blood for analyses was sampled at $43 \mathrm{~d}$ of age. Results: After the rearing period finished at the age of six months, young bulls and steers had similar body weights (176.17 and $176.55 \mathrm{~kg})$ and approximate average daily weight gains from birth $(0.756$ and $0.767 \mathrm{~g} /$ day $)$. The healthy calves at six months of age weighed $180.47 \mathrm{~kg}$, whereas the animals which at least once suffered from some diseases during rearing were lighter by approx. $30 \mathrm{~kg}(\mathrm{P} \leq 0.01)$. A statistically significant $(\mathrm{P} \leq 0.01)$ difference was found for the count of red blood cells and white blood cells. In comparison with healthy individuals, the diseased animals had less RBC (8.33 and $9.4210^{12} / \mathrm{L}$ respectively) and more WBC (27.03 and $12.2610^{9} / \mathrm{L}$ respectively). Conclusion: Castration of young bulls did not have any impact on the results of rearing and health status of the calves. The magnitude of the analysed parameters depended on the health status of the calves. Thus RBC and WBC parameters may be used to predict the health status of calves during rearing.
\end{abstract}

Keywords: calves, gender, rearing, blood parameters, performance.

\section{Introduction}

In Poland, cattle are predominantly reared for milk. The participation of beef breeds in the whole population is only $1 \%$. Therefore, beef originates mainly from dairy breeds and does not always meet the requirements of consumers. Among the slaughtered young cattle, young bulls constitute approx. $72 \%$ and $28 \%$ are heifers (1). Steers are not fattened. In order to improve the quality of beef, commercial crossbreeding of local cattle breed with beef cattle is practised. Steer fattening may also be a way to change the quality of beef as steers' meat is of lighter colour and more tender. Optimal rearing of calves is the basis for achieving good fattening results. Body weight at separation and at the end of rearing (at six months of age) as well as daily weight gains in this period depend on the level of feeding, gender, and health status of calves. It was found that comparable rearing results can be obtained with different systems and feeding strategies with milk feeds. In general, higher weight gains are achieved by young bulls than by steers and heifers (14). Differences in body weight between young bulls and steers of the same age depend on the timing of castration (7). To benefit from the high growth potential of young bulls, it is suggested to perform castration at the final stage of rearing. However, considering animal welfare, castration at a younger age 
is more beneficial because the level of stress reaction in such animals is lower. Castration-induced stress results directly in reduced productivity, causing a drop in daily weight gains and indirectly increasing susceptibility to diseases $(3,15,16,21)$. Diarrhoea and respiratory diseases are the main cause of morbidity in calves during rearing (22). A decision to implement treatment is taken based on observations of clinical symptoms. However, the level of some biochemical blood indicators may also be used to this end as evidenced by the studies of Jagos et al. (10), Martin and Lumsden (14), Pekcan et al. (19), and Stojević et al. (24). This is of particular importance as calves are often diseased without any visible symptoms.

The objective of the study was to determine the relationship between the category and health status in calves, and the results of their rearing and the levels of selected blood parameters before the start of observations.

\section{Material and Methods}

Animals. The study included 105 Polish HolsteinFriesian/beef (Limousine, Charolaise and Hereford) crossbred calves. Young bulls were purchased at the age of two to four weeks from different locations. After purchase, a two-week quarantine was implemented during which the calves were dehorned and 46 young bulls were castrated. The germ horns were removed by burning out. Castration was carried out with a bloodless method using a rubber band.

Feeding. The calves were milk-fed with a milk replacer administered via teats from automated milkfeeding stations. The daily dose of liquid feed was $8 \mathrm{~L}$ at the age of two to four weeks, $6 \mathrm{~L}$ between week five and seven, $4 \mathrm{~L}$ between week eight and eleven, and $3 \mathrm{~L}$ between week eleven and thirteen. One $\mathrm{kg}$ of milk replacer contained: $22 \%$ of total protein, up to $0.8 \%$ of crude fiber, and $15 \%$ of crude fat with water at a $1: 8$ ratio. During the period of liquid feeding, the calves had unlimited access to concentrate and hay. Hay was composed of the first swath of dried grass mixture and concentrate containing maize grain and oat administered simultaneously with liquid feeding. The end of liquid feeding was set at the body weight of $135 \mathrm{~kg}$ for young bulls and $130 \mathrm{~kg}$ for steers. Having been liquid-fed, the calves were fed grass silage ad libitum and the concentrate at $2.5 \mathrm{~kg} / \mathrm{animal} / \mathrm{day}$. The chemical composition and nutritional value of feeds are presented in Table 1. The concentration of basic components was determined with standard methods (4) and NDF and ADF with the method by Van Soesta et al. (25). The nutritional value of solid feeds was determined based on the chemical composition according to IZ PIB-INRA (9).

Body weight control. The calves were weighed at two-week intervals. Body mass was determined using an electronic scale for animals and the measurements were always taken in the morning before feeding. Based on the measurements, the average daily weight gains were calculated by dividing the weight gains in the period between measurements by the number of days in a period.

Health status control. Throughout the rearing period, experienced staff monitored the health status of the calves. Behaviour, feed intake, respiration, and faecal consistency were observed. All deviations from the standards were reported to a veterinarian who decided whether to implement treatment. On this basis, the calves were divided into two groups: the first included healthy animals (90 heads) whilst the second comprised individuals that were ill and needed veterinary treatment at least once during the rearing period. The reasons for veterinary treatment were different, and the group of diseased calves comprised 15 animals - eight bulls and seven steers.

Blood sampling and analyses. At the beginning of the observation period at the age of $43 \mathrm{~d}$, blood was sampled from all calves. The blood was collected from the jugular vein into two tubes: $2 \mathrm{~mL}$ of blood for haematology into a tube without additives and $9 \mathrm{~mL}$ of blood for biochemistry into a tube with K2 EDTA. The haematological parameters were measured in the whole blood directly after sampling (within $2 \mathrm{~h}$ ) with a BC2800Vet automated analyser (Mindray, China). The biochemical parameters were determined in serum obtained after blood centrifugation at $300 \mathrm{rpm}$ for $10 \mathrm{~min}$. The serum was stored at $-80^{\circ} \mathrm{C}$ until analyses. The measurements were taken with a photometric method on a BS 120 biochemical analyser (Mindray, China). Absorbance was recorded at wavelengths from 340 to $670 \mathrm{~nm}$. The content of immunoglobulins in the blood samples was determined with ELISA. The commercial sets suitable for measurements of immunoglobulins in bovine serum (Bethyl Laboratories, USA) were used. The concentration of immunoglobulins was determined with an ELISA reader by taking an absorbance measurement at $450 \mathrm{~nm}$.

Statistical analysis. The results were statistically processed with Statistica v. 10 (23). The impact of the category (young bulls - 59 animals, steers - 46 animals) and health status (healthy - 90 animals, diseased - 15 animals) on the magnitude of daily weight gains, body weight at six months of age and the level of selected blood parameters was determined using the analysis of variance with the following model:

$\mathrm{Y}_{\mathrm{ij}}=\mu+\mathrm{A}_{\mathrm{i}}+\mathrm{B}_{\mathrm{j}}+(\mathrm{AB})_{\mathrm{ij}}+\mathrm{e}_{\mathrm{ij}}$

where:

$\mathrm{Y}_{\mathrm{ij}}$ - value of the analysed parameter,

$\mu$ - mean for the population,

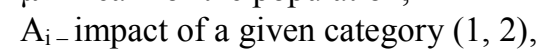

$B_{j}$ - impact of health status $(1,2)$,

$(\mathrm{AB})_{\mathrm{ij}}$ - interaction category $\mathrm{x}$ health status, $\mathrm{e}_{\mathrm{ij}-\text { random error. }}$

The significance of differences was estimated by Tukey's test at the level of 0.05 . 
Table 1. Chemical composition and nutritional value of experimental feeds

\begin{tabular}{|c|c|c|c|c|c|}
\hline Specification & Milk replacer * & Hay & Grass silage & Concentrate I & Concentrate II \\
\hline Dry matter (DM), g/kg & 965 & 867 & 408 & 875 & 876 \\
\hline \multicolumn{6}{|l|}{ Content in DM:, g/kg } \\
\hline Organic matter & 976 & 919 & 827 & 827 & 900 \\
\hline Crude fat & 100 & 14 & 39 & 21 & 17 \\
\hline NDF & & 576 & 529 & 185 & 189 \\
\hline $\mathrm{NE} \mathrm{MJ**}$ & & 4.8 & 5.32 & 6.94 & 6.96 \\
\hline NEL MJ & 11.59 & & & & \\
\hline
\end{tabular}

* declared by the manufacturer

**NE MJ - acc to IZ PIB-INRA, 2009

$* * *$ acc to DLG, 1997

Table 2. Results for calves reared up to the age of six months by categories and health status

\begin{tabular}{|c|c|c|c|c|c|c|c|c|}
\hline \multirow{4}{*}{ Specification } & \multirow{4}{*}{ Category (C) } & \multicolumn{4}{|c|}{ Health status (HS) } & \multirow{2}{*}{\multicolumn{2}{|c|}{ Total }} & \multirow{2}{*}{$\begin{array}{c}\text { Interaction } \\
\mathrm{C} \times \mathrm{HS}\end{array}$} \\
\hline & & \multicolumn{2}{|c|}{ Healthy } & \multicolumn{2}{|c|}{ Sick } & & & \\
\hline & & - & & - & & - & & \\
\hline & & $x$ & SEM & $x$ & SEM & $x$ & SEM & $P$ - value \\
\hline \multirow{3}{*}{ Age at weaning (days) } & Bulls & 117.90 & 3.63 & 150.77 & 3.92 & 123.47 & 3.47 & \multirow{3}{*}{0.031} \\
\hline & Steers & 111.31 & 3.23 & $161.14^{*}$ & 4.00 & 116.72 & 3.94 & \\
\hline & Total & 114.90 & 2.47 & $154.23 * *$ & 5.19 & 120.51 & 2.61 & \\
\hline \multirow{3}{*}{$\begin{array}{l}\text { Body weight at the age of } \\
182 \mathrm{~d}(\mathrm{~kg})\end{array}$} & Bulls & $180.34 *$ & 3.59 & 155.74 & 7.66 & 176.17 & 3.45 & \multirow{3}{*}{0.399} \\
\hline & Steers & $180.48 * *$ & 3.26 & 144.33 & 8.42 & 176.55 & 3.45 & \\
\hline & Total & $180.47 * *$ & 2.44 & 151.93 & 5.88 & 176.34 & 2.45 & \\
\hline \multicolumn{9}{|l|}{ Average daily gain $(\mathrm{kg})$} \\
\hline \multirow{3}{*}{ Pre-weaning } & Bulls & $0.759 * *$ & 0.024 & 0.457 & 0.022 & 0.708 & 0.025 & \multirow{3}{*}{0.539} \\
\hline & Steers & $0.765 * *$ & 0.026 & 0.522 & 0.071 & 0.739 & 0.027 & \\
\hline & Total & $0.762 * *$ & 0.018 & 0.478 & 0.028 & 0.721 & 0.018 & \\
\hline \multirow{3}{*}{ Post-weaning } & Bulls & 0.929 & 0.105 & 1.250 & 0.179 & 0.953 & 0.092 & \multirow{3}{*}{0.793} \\
\hline & Steers & 0.914 & 0.035 & $1.224 *$ & 0.232 & 0.925 & 0.039 & \\
\hline & Total & 0.922 & 0.059 & 1.242 & 0.140 & 0.940 & 0.055 & \\
\hline \multirow{3}{*}{ Overall (0-182 d) } & Bulls & 0.788 & 0.020 & 0.652 & 0.016 & 0.756 & 0.017 & \multirow{3}{*}{0.399} \\
\hline & Steers & $0.788^{*}$ & 0.018 & 0.590 & 0.046 & 0.767 & 0.019 & \\
\hline & Total & $0.788 *$ & 0.013 & 0.632 & 0.019 & 0.766 & 0.013 & \\
\hline
\end{tabular}

Mean values in horizontal rows are significantly different: ${ }^{*}-\mathrm{P}<0.05 ; * *-\mathrm{P}<0.01$

\section{Results}

Performance. The average age of the calves at the beginning of observation was $43 \mathrm{~d}$. Liquid feed was fed to young bulls up to $135 \mathrm{~kg}$ and to steers up to $130 \mathrm{~kg}$. The performance results for the calves are presented in Table 2. The period of milk feeding lasted for an average of $120 \mathrm{~d}$. The young bulls reached the assumed body weight six days later than the steers. Their daily weight gains in this period were $0.708 \mathrm{~kg}$ and were slightly lower than those of the steers. In the postweaning period, the daily weight gains of the calves increased, amounting to $0.940 \mathrm{~kg}$ on average. At that time, the young bulls had higher gains than the steers. At the age of six months, all calves had the same body weight and comparable daily weight gains from birth till six months of age. The performance results were diversified by health status. The animals that were 
diseased had statistically significantly $(\mathrm{P} \leq 0.01)$ lower daily weight gains, a longer period of liquid feeding and lower body weight at six months of age. After separation, daily weight gains in the calves that were previously diseased were higher than those in the calves previously categorised as "healthy".

Blood parameters. The evaluation of haematological parameters involved 59 young bulls and 46 steers, with 15 animals out of the total considered as unhealthy (Tables 3 and 4). The average values of analysed parameters (except WBC) were within a wide range of reference values $(5,27)$. No differences between young bulls and steers were found. The values of the analysed parameters depended on the health status of the calves. The diseased calves had a statistically significantly $(\mathrm{P} \leq 0.01)$ lower number of $\mathrm{RBC}$ and higher counts of WBC (including lymphocytes) than healthy calves. In addition, in the diseased calves there was a decreased level of glucose and increased concentration of total protein in blood serum; however, these differences were not confirmed statistically. The analysis of the concentration of immunoglobulins in blood serum demonstrated that calves which needed veterinary treatment at least once during the rearing period had a higher level of $\operatorname{IgG}$ and lower levels of $\operatorname{IgM}$ and $\operatorname{IgA}$ than their healthy counterparts, although the difference was not confirmed statistically.

\section{Discussion}

In Poland, steer rearing and fattening is not a part of traditional animal production. The selection of timing and method of castration were thus influenced by the results reported by other authors. The age of castration and the procedure impair animal welfare and reduce daily weight gains $(15,21,26)$. Studies on both timing (after birth, at six or twelve months of age) and the method of castration (with a rubber band or surgically) carried out by Knight et al. (12) showed that the age of castration did not differentiate the body weight of steers at slaughter. It causes a transient reduction of daily weight gains. Fisher et al. (8) did not demonstrate any differences in the stress level after castration performed with different methods. According to Mellor et al. (17), the level of stress may be higher when the animals are castrated at the older age. Considering this and the age of calves at purchase, in the present study the young bulls were castrated before puberty and the average age at castration was $37 \mathrm{~d}$. The conducted study did not find any differences between young bulls and steers in the size of daily weight gains during rearing or body mass at the age of six months. This finding is consistent with observations of other authors.

Table 3. Blood parameters for calves with regard to their health status and category

\begin{tabular}{|c|c|c|c|c|c|c|c|c|}
\hline \multirow{3}{*}{ Specification } & \multirow{3}{*}{$\begin{array}{l}\text { Category } \\
\text { (C) }\end{array}$} & \multicolumn{4}{|c|}{ Health status (HS) } & \multicolumn{2}{|c|}{ Total } & \multirow{3}{*}{$\begin{array}{c}\text { Interaction } \\
\text { C x HS } \\
\text { P - value }\end{array}$} \\
\hline & & \multicolumn{2}{|c|}{ Healthy } & \multicolumn{2}{|c|}{ Sick } & \multirow[b]{2}{*}{$\bar{x}$} & \multirow[b]{2}{*}{ SEM } & \\
\hline & & $\bar{x}$ & SEM & $\bar{x}$ & SEM & & & \\
\hline \multirow{3}{*}{$\operatorname{RBC}\left(10^{12} / \mathrm{L}\right)$} & Bulls & 9.45 & 0.25 & 8.64 & 0.77 & 9.32 & 0.25 & \multirow{3}{*}{0.369} \\
\hline & Steers & $9.38 * *$ & 0.19 & 7.70 & 0.67 & 9.19 & 0.20 & \\
\hline & Total & $9.42 *$ & 0.16 & 8.33 & 0.56 & 9.26 & 0.16 & \\
\hline \multirow{3}{*}{$\operatorname{WBC}\left(10^{9} / \mathrm{L}\right)$} & Bulls & 12.11 & 1.54 & 23.32 & 11.62 & 14.01 & 2.34 & \multirow{3}{*}{0.271} \\
\hline & Steers & 12.43 & 1.12 & $34.45 * *$ & 20.17 & 14.83 & 2.44 & \\
\hline & Total & 12.26 & 0.98 & $27.03 * *$ & 9.93 & 14.37 & 1.69 & \\
\hline \multirow{3}{*}{$\operatorname{Limf}\left(10^{9} / \mathrm{L}\right)$} & Bulls & 5.76 & 0.98 & 14.27 & 9.82 & 7.2 & 1.84 & \multirow{3}{*}{0.127} \\
\hline & Steers & 5.03 & 0.75 & $25.72 * *$ & 8.10 & 7.28 & 2.13 & \\
\hline & Total & 5.43 & 0.63 & $18.39 * *$ & 8.64 & 7.24 & 1.39 & \\
\hline \multirow{3}{*}{ GLU (mg/dL) } & Bulls & 73.04 & 2.19 & 66.80 & 3.44 & 71.98 & 1.92 & \multirow{3}{*}{0.279} \\
\hline & Steers & 72.93 & 2.65 & 76.80 & 8.70 & 73.35 & 2.52 & \\
\hline & Total & 72.99 & 1.69 & 70.13 & 3.72 & 72.58 & 1.54 & \\
\hline \multirow{3}{*}{$\mathrm{TP}(\mathrm{g} / \mathrm{dL})$} & Bulls & 5.12 & 0.08 & 5.30 & 0.12 & 5.15 & 0.07 & \multirow{3}{*}{0.529} \\
\hline & Steers & 5.00 & 0.07 & 4.98 & 0.41 & 5.00 & 0.08 & \\
\hline & Total & 5.07 & 0.06 & 5.19 & 0.15 & 5.08 & 0.05 & \\
\hline
\end{tabular}

Mean values in horizontal rows are significantly different: * $-\mathrm{P}<0.05 ; * *-\mathrm{P}<0.01$ 
Table 4. Blood protein profile by category and health status

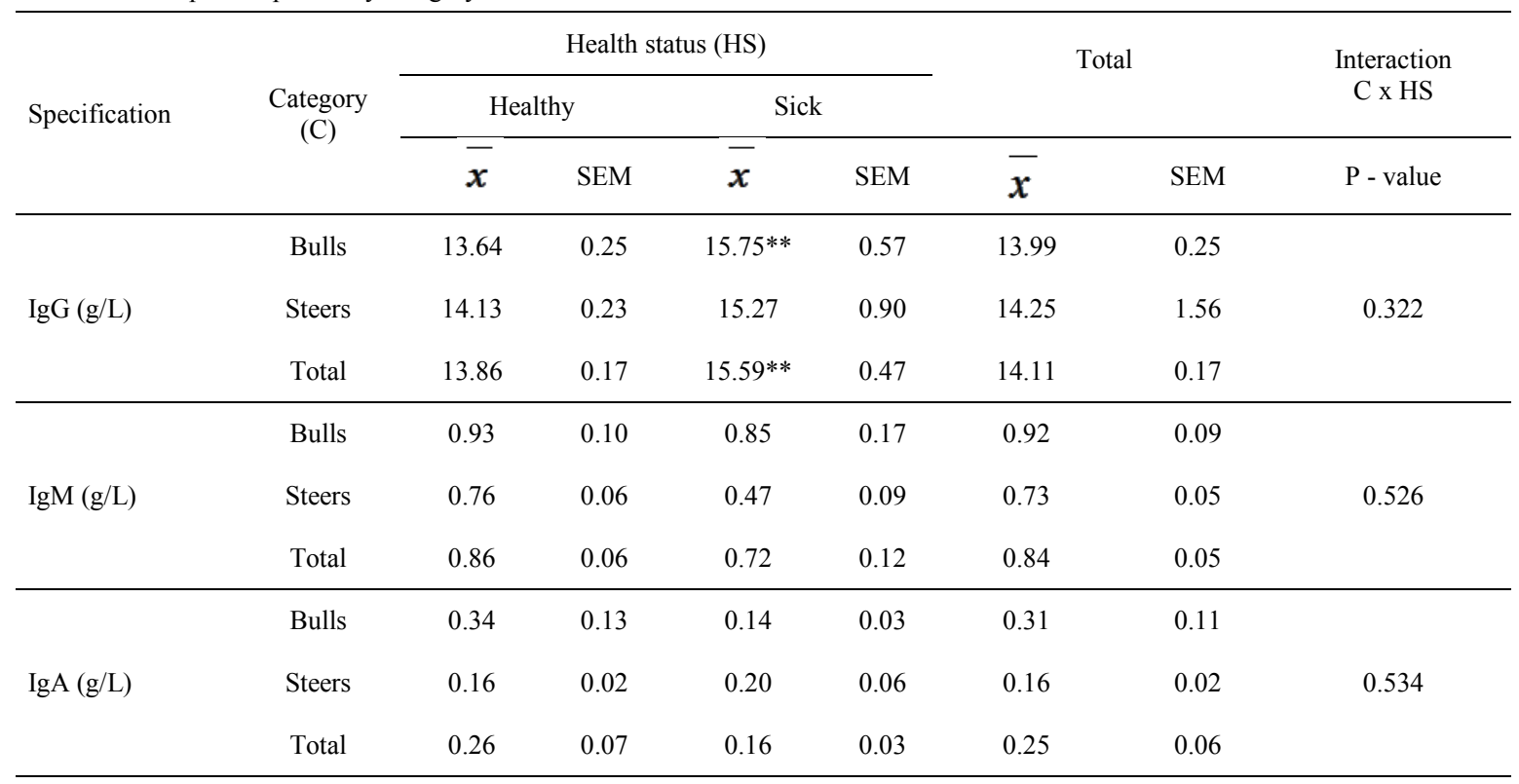

Mean values in horizontal rows are significantly different: $* *-\mathrm{P}<0.01$

As androgens are responsible for the development of secondary external sexual features (growth of neck muscles and shoulder area), differences in productivity between young bulls and steers are seen mainly after puberty (10). Bretschneider (7) also reported that castration of calves at birth allows animals to achieve the same body weight at the age of six to nine months as intact individuals.

A reduction in daily weight gains after castration is caused not only by stress, but also by higher susceptibility of animals to diseases $(16,20)$, especially when castration is performed at the older age (15). In the present study, no significant impact of castration on the incidence of diseases in the calves was recorded. Treatment was needed in $17 \%$ of the young bulls and $16 \%$ of the steers. In the present study, there were no differences recorded between young bulls and steers in haematological parameters. The analysed blood indices were within a wide range of reference values $(5,27)$. However, Pavlik et al. (18) found that gender had an impact on the level of total protein in blood serum; the heifers had a significantly higher $(\mathrm{P}<0.05)$ concentration of total protein than young bulls. In the present study, no signs of diseases were recorded in tested blood parameters. Nevertheless, it was found that the values of blood parameters at the beginning of the experiment were associated with health status during rearing. The diseased calves had a statistically significantly $(\mathrm{P} \leq 0.01)$ lower number of $\mathrm{RBC}$ and a higher count of WBC, including lymphocytes, than healthy animals. Martin and Lumsden (14) also noted differences between healthy and diseased calves, and these findings may be used to predict future health status. An increase in the number of WBC indicates inflammatory processes in the body. Aksionova and Nikulina (2) also found that the beginning of disease in animals led to a decrease in erythrocyte count in blood.
Litwińczuk et al. (13) found differences in haematological profile of blood between calves slaughtered in summer and autumn. Higher percentage of WBC and significantly higher lymphocyte count were shown by calves slaughtered in summer. However, Winnicka (27) reported that in cattle, especially in young ruminants, this parameter undergoes substantial fluctuations and is therefore less important in predicting health status compared to other animal species. In the diseased animals, there was a tendency towards a reduction in the level of glucose and an increase in the concentration of total protein in blood serum. These differences were not confirmed statistically. Jagos et al. (10) and Pekcan et al. (19) reported a statistically significant reduction in the concentration of glucose in blood serum in calves during bronchopneumonia and diarrhea, and these authors believe that this parameter may be a diagnostic tool. In the present study, the analysis of blood parameters was performed at the beginning of observations, i.e. after purchase and quarantine at the age of $43 \mathrm{~d}$, and changes in the level of glucose were therefore statistically insignificant. No statistically significant difference in the concentration of measured immunoglobulins in blood serum collected from healthy and diseased calves was recorded. Moreover, it was not confirmed that calves with a lower level of immunoglobulins were ill more often. Both in the group of healthy calves and in the animals showing symptoms of a disease at least once during the experiment there were animals with very high and very low levels of passive immunity indices. It is thus concluded that the concentration of measured immunoglobulins in blood serum did not have any relation to the category or health status of the calves. The results are consistent with the findings reported by Ježek et al. (11) and Bender and Bostedt (6) who did 
not record any statistically significant relation between the concentration of $\operatorname{IgG}$ and $\operatorname{IgM}$ in blood serum and the incidence of diseases in calves. However, Jagos et al. (10) and Pekcan et al. (19) found a higher level of globulin proteins in blood serum of calves with diarrhoea and bronchopneumonia, and reported that it might be associated with inflammatory conditions.

In conclusion, it was demonstrated that early castration of young bulls did not have any negative impact on their health status, blood parameters, or body weight at the end of rearing period (i.e. at the age of six months). The magnitude of the analysed features depended on the health status of the calves. The performance parameters were diversified by the health condition of the calves. The animals that were ill had lower daily weight gains, longer period of liquid feeding, and lower body weight at the age of six months in comparison to healthy animals. A lower number of $\mathrm{RBC}$ and a higher number of $\mathrm{WBC}$ in animals without any visible disease symptoms may be indicative of their future health status. These parameters may thus be used to predict the health condition of calves during rearing.

Conflict of Interests Statement: The authors declare that there is no conflict of interests regarding the publication of this article.

Financial Disclosure Statement: The study was performed within the Project WND-POIG.01.03.01-00204/09 Optimising of Beef Production in Poland According to "From Farm to Fork" Strategy cofinanced by the European Regional Development Fund under the Innovative Economy Operational Programme 2007-2013.

Animal Rights Statement: The authors declare that the experiments on animals were conducted in accordance with the local Ethical Committee laws and regulations as regards care and use of laboratory.

\section{References}

1. Agricultural Markets; 17/2014, $5^{\text {th }}$ May, 8, 2014. http://www. minrol. gov.pl.

2. Aksionova V.M., Nikulina N.B.: The morphological research of calves' erythrocytes and neutrophils during acute bronchopneumonia. Life Sci J 2014, 11, 322-325.

3. Alsaad K.M., Al-Obaidi Q.T., Hassan S.D.: Clinical, haematological and coagulation studies of bovine viral diarrhoea in local Iraqi calves. Bulg J Vet Med 2012, 15, 44-50.

4. AOAC. Association of Official Analytical Chemists. Official Methods of Analysis. Arlington. 2005.

5. Baumgartner W.: Klinische Propadeutic der inneren Krankheiten und hautkrankheiten der Haus- und Heimtiere. Parey, Berlin, 2005.

6. Bender P., Bostedt H.: Determination of IgG and IgM levels in sera of newborn calves until the $10^{\text {th }}$ day of life by ELISA and description of their correlation to total plasma protein concentration and GGT activity. Dtsch Tierärztl Wochenschr 2009, 116, 44-52.
7. Bretschneider G.: Effects of age and method of castration on performance and stress response of beef male cattle: A review. Liv Prod Sci 2005, 97, 89-100.

8. Fisher A.D., Knight T.W., Cosgrove G.P., Death A.F., Anderson C.B., Duganzich D.M., Matthews L.R.: Effects of surgical or banding castration on stress responses and behaviour of bulls. Austr Vet J 2001, 79, 279-284.

9. IZ PIB-INRA. Normy żywienia bydła, owiec i kóz. Wyd. Strzetelski J., Kraków 2009.

10. Jagos P., Bouda J., Dvorak V., Ondrová J.: Comparison of biochemical parameters in the blood of healthy and diseased calves in a large barn. Vet Med 1981, 26, 573-580.

11. Ježek J., Nemec M., Malovrh T., Klinkon M.: Indicators of passive immunity and health status of calves. Acta Vet (Beograd) 2010, 60, 513-523.

12. Knight T.W., Cosgrove G.P., Death A.F., Anderson C.B.: Effect of age of pre- and post-pubertal castration of bulls on growth rates and carcass quality. New Zeal J Agric Res 2000, 43, 585588.

13. Litwińczuk Z., Florek M., Kędzierska-Matysek M., Skałecki P.: Blood haematological profile and meat colour of calves slaughtered in summer and autumn season. Pol J Vet Sci 2009, $12,557-562$.

14. Martin S.W., Lumsden J.H.: The relationship of hematology and serum chemistry parameters to treatment for respiratory disease and weight gain in Ontario feedlot calves. Can J Vet Res 1987, 51, 499-505.

15. Massey C., Dhuyvetter K.C., Llewelyn R.V., Blasi D.A.: Castration and morbidity and their effects on performance, carcass quality, and price differentials for bulls and steers. Prof Anim Sci 2011, 27, 19-28.

16. McGuirk S.M.: Disease management of dairy calves and heifers. Vet Clin North Am Food Anim Pract 2008, 24, 139-153.

17. Mellor D.J., Molony V., Robertson I.S.: Effects of castration on behaviour and plasma cortisol concentrations in young lambs, kids and calves. Res Vet Sci 1991, 51, 149-154.

18. Pavlík A., Zahrádková R., Bureš D., Jelínek P., Havlíček Z.: Indicators of the internal environment of Gasconne calves during rearing. Acta Vet Brno 2009, 78, 37-45.

19. Pekcan M., Altintas A., Karagul H., Fidanci U., Uysal H., Besalti O., Unubol A.S., Ciftci G., Bilgihan S., Hanedan B.: Serum biochemistry and native protein electrophoresis in diarrheic calves with arthritis. Acta Vet (Beograd) 2012, 62, 261-269.

20. Ratcliff M.D., Kegley E.B., Krumpelman S.L., Hornsby J.A.: Effect of method and timing of castration on newly arrived stocker cattle. Ar Anim Sci Depart Rep 2005, 115-117.

21. Ratcliff M.D., Kegley E.B., Powell J.G., Hawley J., Lusby K.S., Rowe M.P., Gunter S.A., Daniels L.B., Hubbell D.S.: Effect of method and timing of castration on newly arrived stocker cattle. Prof Anim Scient 2014, 30, 457-465.

22. Snowder G.D., van Vleck L.D., Cundiff L.V., Bennett G.L.: Bovine respiratory disease in feedlot cattle: Environmental, genetic, and economic factors. J Anim Sci 2006, 84, 1999-2008.

23. StatSoft Inc., STATISTICA, data analysis software system, version $10^{\text {th }}$, www.statsoft.com. 2013.

24. Stojević Z., Filipović N., Božić P., Tuček Z., Daud J.: The metabolic profile of Simmental service bulls. Vet Arhiv 2008, 78, 123-129.

25. Van Soest P.J., Robertson J.B., Lewis B.A.: Methods for dietary fiber, neutral detergent fiber and non-starch polysaccharides in relation to animal nutrition. J Dairy Sci 1991, 74, 3583-3597.

26. Warnock T.M., Thrift T.A., Irsik M., Hersom M.J., Yelich J.V., Maddock T.D., Lamb G.C., Arthington J.D.: Effect of castration technique on beef calf performance, feed efficiency, and inflammatory response. J Anim Sci 2012, 90, 2345-2352.

27. Winnicka A.: Wartości referencyjne podstawowych badań laboratoryjnych w weterynarii. Wyd. SGGW, Warszawa, 2001. 